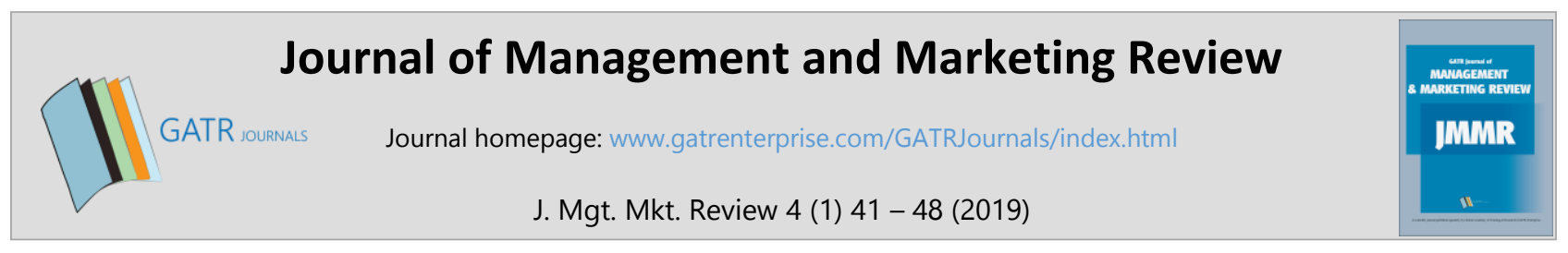

\title{
Model for Strengthening Employee Performance
}

\author{
Tjiptogoro Dinarjo Soehari, ${ }^{1 *}$ Rina Uswatun Hasanah, ${ }^{2}$ dan M. Havidz Aima ${ }^{3}$ \\ $1^{*}$ Lecturer of Mercu Buana University, Jakarta - Indonesia \\ ${ }^{2}$ Post Graduate Alumni of Mercu Buana University \\ ${ }^{3}$ Lecturer of Mercu Buana University, Jakarta - Indonesia
}

\begin{abstract}
Objective - The instability of employee performance in the last three years requires a solution to strengthen employee performance. This study aims to develop a model for strengthening employee performance.

Methodology/Technique - This study uses quantitative exploratory techniques with SPSS software, with the following independent variable: Employee Performance (Y), and dependent variables: Organizational Change (X1), Organizational Culture (X2), and Achievement Motivation (X3). The case study is conducted in the Jakarta Islamic Centre, which has a population of 46 people.

Findings - The regression Results (1) of the regression equation are $\mathrm{Y}=0.099+0.148 \mathrm{X} 1+0.037 \mathrm{X} 2+0.797 \mathrm{X} 3$; RSq $=0.737:$ F calculated 35.435 with $\mathrm{Sig}=0,000$. The findings show that employee achievement motivation is a factor that determines high employee performance, organizational changes and organizational culture have no significant effect but when taken together with motivation, have a significant influence on employee performance.

Novelty - If there is no policy or implementation of organizational change, organizational culture, and motivation to support employee performance, then employee performance will be low, around 0.099 on scale 1-5.
\end{abstract}

Type of Paper: Empirical.

JEL Classification: M10, M14, M19.

Keywords: Organizational Change; Organizational Culture; Motivation; Employee Performance.

\section{Introduction}

Jakarta Islamic Center (JIC) is a mosque-based institution that is managed together by the government and community as an effort to empower people in all fields. There are many methods of employee motivation that have been tested at the Jakarta Islamic Center such as Sufism courses, mental processing exercises (heart management), Emotional and Spiritual Question (ESQ), Work Spirituality Improvement training, training to be happy workers, etc. JIC is a center for Islamic studies and development, which was founded in the New Order era, although it has now entered the reform era and the post-reform JIC continues to grow.

* Paper Info: Revised: January 18, 2019

Accepted: March 03, 2019

* Corresponding author: Tjiptogoro Dinarjo Soehari

E-mail: tjiptogd@yahoo.com

Affiliation: Lecturer of Mercu Buana University, Jakarta - Indonesia 
The change of the new order government to the reform era had a positive influence through the emergence of bureaucratic reform, as well as the transformation of programs and organizational structures that continue gradually today. The development of the JIC cannot be separated from the roles and regulation of government, which has an impact on organizational change, organizational culture and employee motivation which has a consequential effect on employee performance. These changes can have either a positive or negative effect. Hence, research on the impact of organizational change, organizational culture, and work motivation on employee performance is critical as it relates to human resources, which is the main driver of change.

The Board of Management of the JIC (BM-JIC) strives to make improvements in all fields, complementing the facilities and infrastructure needed and other actions that are closely related to improving performance. The results of the pre-research conducted show that the employees performance of the JIC still needs to be improved. In 2014-2016, the number of employees who were sick and had very poor performance fluctuated between $12.3 \%-17.4 \%$, This result indicates a need for the management of the JIC to focus on improving employee performance, particularly in this area.

Individual depth interviews (IDI) were conducted with several officers to obtain data on the dynamics within the organization related to employee performance, organizational change, organizational culture, and motivation. The results of the IDI are consistent with the pre-study questionnaire given to 30 respondents with indicates that organizational change, organizational culture, and motivation all have an effect on employee performance. This is the focus of the present research.

\section{Literature Review}

\subsection{Organizational Change}

Griffin et. al. (2017:554) argues that an institution must continue to make changes to survive and develop its vision, mission and duties. Institutions that do not make real changes will lose the ability to compete, will be unable to perform optimally, and are susceptible to takeovers by other market players.

Not all organizational change can be predicted and therefore not all change can be handled efficiently. The four factors that appear to be the most powerful in putting pressure on change are people, technology, information processing and communication, and competition. Brown and Harvey (2006:215) argue that the three basic strategies for organizational change are structural, technological and behavioral. These three approaches are separate from one another, but in practice, changes implemented using any one of those strategies will most likely require some use of the other two strategies. Structural strategies prioritize the organization's design and workflow, such as reporting structures. Changes in company structure include changes in authority relationships, coordination mechanisms, job design, or similar structural variables. The technology strategy applies new technological developments to areas related to strategic innovation changes in technology implemented by modifying works that are processed according to the methods and equipment used. Behavioral strategies develop the use of human resources, such as empowering people at the lowest level of the organization to make decisions without seeking approval from those at a higher level.

\subsection{Organizational Culture}

Robbins (2007:511), argues that organizational culture is a system of shared meanings held by members that distinguish an organization from other organizations. Organizational culture is a rule that exists within the company that serves as a guide for human resources in carrying out their obligations and values to behave in the organization. The seven dimensions of organizational culture are: (1) innovation and the courage to take risks (the extent to which employees are encouraged to be innovative and take risks), (2) attention to detail (the area to which employees are expected to show precision, analysis, and care), (3) result orientation (the extent to which management focuses on results rather than on the techniques and processes used to 
achieve those results), (4) people orientation (the area to which management decisions consider the effect of those results on people within the organization), (5) team orientation (the extent to which work activities are organized in teams rather than individuals), (6) aggressiveness (the area to which people are aggressive and competitive rather than relaxed), and (7) stability (the area to which organizational activities emphasize maintaining the status quo in comparison to the growth of the organization).

Tjiptogoro et. al. (2017) suggests that organizational culture is: (1) the basic philosophy and assumptions of an organization regarding general beliefs, norms and values as the core of an organization, management, and all members as a whole, (2) capacity of innovation, and ability and courage to take risks; (3) ability to carry out the work according to its duties by carrying out analysis and giving detailed attention to matters that affect the success of its work; (4) focusing on outcomes from the process to achieve targeted results; (5) making decisions whilst paying attention to external influences on employees; (6) organizational activities, which prioritize teams rather than individuals; (7) employee aggressiveness to compete in order to find a solution to the completion of the work unit's task to grow is not just carrying out the responsibility of maintaining the status quo.

\subsection{Motivation}

Griffin et. al. (2017:170) argues that motivation is a unity of various forces that cause a person to choose certain behaviors from different alternative behaviors. Managers motivate employees within their organizations to perform well. This means that managers invite employees to work hard, following the provisions of the organization, and contribute positively to the organization's mission. To be able to achieve high performance, they must be able to work effectively (ability) and must have the material, resources, equipment, and information needed to carry out their tasks (environment). Inadequacy in each of these areas will have a negative impact on performance, which can be formulated as follows: $\mathrm{P}=\mathrm{M} \times \mathrm{A} \times \mathrm{E}$, where $\mathrm{P}=$ Performance; $\mathrm{M}=$ motivation; $\mathrm{A}=$ ability; and $\mathrm{E}=$ environment.

Herszberg (1959) in Hasibuan (2007:110) suggests that motivation is a desire in a person that causes the person to act. He suggests that motivation is a willingness to spend a high amount of effort to achieve organizational goals that are conditioned by the ability of the effort to meet individual needs. Two factors influence employees in carrying out their work: (1) motivation about a person's psychological needs consisting of achievement, recognition, the work itself, responsibility, and development of individual potential (advancement); (2) motivation regarding maintenance factors consisting of ages or salaries, working conditions, policy and administration of the company, interpersonal relationships, and the quality of their supervisor.

\subsection{Employee Performance}

Bangun (2012:231) suggests that performance is the work of someone according to their job requirements. Performance can also be interpreted as a specific target management commitment that can be achieved by employees or organizations. Performance is the overall level of success of a person in carrying out a task during a specified period compared to the standard of work, targets or criteria that have been determined and mutually agreed upon. A job can be measured through: (1) the amount of work produced by the individual or groups according to their job requirements. Every position has different requirements and requires employees to meet the requirements of both knowledge, skills and abilities. The job requirements can be used as a basis for identifying the number of employees required to complete the task, or for employees to know how much time they should spend on the particular task (doing work according to the output target that must be produced per person per working hour); (2) each employee must meet specific requirements in order to provide work according to the quality required by a particular job; (3) the character of each position is different, and each task must be completed according to the time specified (in addition to the timely completion of work, employees are also required to arrive on time); (4) a particular job requires the presence 
of employees according to the time specified; (5) not one employee can complete all jobs; certain types of work may have to be completed by two or more employees, thus requiring cooperation between employees.

Employee performance can be assessed by their ability to collaborate with other colleagues, assisting superiors by providing advice to increase company productivity and appreciating their co-workers. Tjiptogoro Dinarjo et. al. (2017) suggests that performance is the process and achievement of one's work according to certain benchmarks, including: (1) the ability to complete work responsibly; (2) capacity in terms of the quantity and quality of work and the timeliness of completion of employment; (3) mastery of the knowledge and skills required to ensure accuracy; (4) reliability in terms of prioritizing the interests of the company; (5) readiness to continue to improve the work to meet the target by continuing to develop themselves according to work demands; (6) independence in terms of being able to work without supervision and establishing cooperation with internal and external parties as well as a willingness to assist others with their tasks.

\section{Research Methods}

The results of the IDI are in line with the pre-study questionnaire given to 30 respondents which concludes that Employee Performance (Y), as the dependent variable, is affected by the following independent variables: Organizational Change (X1), Organizational Culture (X2), and Motivation (X3). The research method used is quantitative explorative analysis using SPSS 24. The population of the study consists of employees of BM-JIC with a total of 46 people.

\section{Findings}

\subsection{Characteristics of the Respondents}

The characteristics of the respondents are as follows: (1) Gender: male $=80.4 \%$ and female $=19.6 \%$; (2) Age: $<30$ years $=17.4 \%, 30-50$ years $=65.1 \%, 51-60$ years $=17.4 \%$. The golden age of employees is 65.1\%; (3) Education: Senior High School $=10.9 \%$, Diploma $=6.5 \%$, Bachelor and Postgraduate $=82.6 \%$; (3) Working Duration: under 5 years $=50 \%$, more than 5 years $=50 \%$; (4) Position in the JIC: the respondents consist of Drivers, General Staff, Heads of Department, Managers, and Senior Managers.

\subsection{Instrument Test}

Validity and reliability tests were carried out on the 30 respondents. A validity test of Organizational Change (X1) shows that out of the 14 instrument items, there are two invalid items, being question No. 3 and article No. 10. Those items obtained validity values below 0.3 and were removed from the study accordingly. The validity of Organizational Culture (X2) shows that, out of the 26 instrument items, two are invalid with a validity $r$ value below 0.3 . Hence, No. 16 and No. 37 were removed from the study. Motivation has 10 items and all of those items have a validity value above 0.3 , hence all of those instruments remain in the study. The validity test for Performance (Y) shows that out of 10 instruments, one instrument has a validity value below 0.3 meaning item No. 52 was removed from the study.

The reliability values of the items are as follows: Organizational Change Test $(\mathrm{X} 1)=0.891$, Organizational Culture $(\mathrm{X} 2)=0.935$, Motivation $(\mathrm{X} 3)=0.866$, and Employee Performance of BM-JIC $(\mathrm{Y})=$ 0.855 , meaning all variables obtained reliability values above 0.6 and were determined to be reliable. 


\subsection{Classic Assumption Test}

\subsubsection{Normality and Multicollinearity}

Normality is tested by using One-Sample Kolmogorov-Smirnov with a significance level of $\alpha=5 \%$. If the significance level is higher than $\alpha=5 \%$, then the data is normally distributed. If the significance level is less than $\alpha=5 \%$, then the data is not normally distributed. Based on the results of data processing test, the results of the normality test using One-Sample Kolmogorov-Smirnov is smaller than 0.05 , so it can be concluded that the data is not normally distributed. The test of the normality of the data using a Z-score shows that samples No. 1 , No. 19 , No. 27 , and No. 34 point to a muted value greater than 2.5 which is rejected. Hence, the number of samples processed is 42 samples. Multicollinearity tests show that the VIF value $<10$ for all independent variables. Thus there is no multicolonization.

\subsection{Multiple Linear Regression Analysis}

Multiple linear regression analysis is used to determine the effect of organizational change, organizational culture and motivation on employee performance. The results are displayed below.

Table 1. Regression Results

\begin{tabular}{|c|c|c|c|c|c|c|}
\hline \multirow{2}{*}{\multicolumn{2}{|c|}{ Model }} & \multicolumn{2}{|c|}{ Unstandardized Coefficients } & \multirow{2}{*}{$\begin{array}{c}\text { Standardized } \\
\text { Coefficients } \\
\text { Beta } \\
\end{array}$} & \multirow[b]{2}{*}{$\mathrm{t}$} & \multirow{3}{*}{$\begin{array}{l}\text { Sig. } \\
0.826\end{array}$} \\
\hline & & B & Std. Error & & & \\
\hline & (Constant) & 0.099 & 0.448 & & 0.222 & \\
\hline & Organizational Change & 0.148 & 0.170 & 0.121 & 0.871 & 0.389 \\
\hline & Organizational Culture & 0.037 & 0.198 & 0.030 & 0.187 & 0.853 \\
\hline & Motivation & 0.797 & 0.117 & 0.767 & 6.824 & 0.000 \\
\hline
\end{tabular}

Source: Data is processed bv SPSS 24.

The testing of the hypothesis is conducted by testing the determination coefficient ( $\mathrm{R}$ Square), simultaneous significance test (Statistical Test F), and testing the significance of individual parameters (Statistical Test t) using SPSS version 24 (see Table 1). Based on the results above, the data can be entered into the regression equation as follows:

$$
\mathrm{Y}=0.099+0.148 \mathrm{X} 1+0.037 \mathrm{X} 2+0.797 \mathrm{X} 3
$$

$\mathrm{Y}=$ Employee Performance;

$\mathrm{X} 1$ = Organizational Change;

$\mathrm{X} 2$ = Organizational Culture;

X3 = Motivation

The above equation can be explained as follows:

1. Constant $=0.099$. If the independent variables (organizational changes, organizational culture and motivation) do not exist or are equal to zero, then employee performance is equal to 0.099 , and $\mathrm{Sig}=$ $0.826>0.05$ (not significant). This demonstrates inferior performance.

2. Regression coefficient of organizational change $=0.148$ and Sig $=0.389>0.05$ (not significant). This mean that organizational change does not have a positive effect on employee performance. 
3. Regression coefficient of organizational culture $=0.037$ and $\mathrm{Sig}=0.853>0.05$ (not significant). This mean that organizational culture cannot be used to improve employee performance.

4. Regression coefficient of motivation $=0.797$ and $\mathrm{Sig}=0.000<0.05$ (significant). This mean that motivation can be used to improve employee performance.

\subsection{Determinant and Simultaneous Test}

The determinant value of the $\mathrm{R}$ Square (RSq) ranges from 0 to 1 . The results of the calculation of $\mathrm{RSq}$ value $=0.737$, demonstrating that $\mathrm{X} 1, \mathrm{X} 2$, and $\mathrm{X} 3$ can be used to explain $\mathrm{Y}$ by up to $73.7 \%$, while the other factors explain the remaining $26.3 \%$.

This F statistic test is used to test the hypothesis proposed in this study. The results of the test F-count is 35.435 with a significance value of 0.000 , which is smaller than 0.05 . It can therefore be concluded that the variables of organizational change, organizational culture, and motivation simultaneously affect employee performance.

\section{Discussion}

The value of constant factor of the equation regression indicates that if no policy of organizational change, organizational culture, and motivation are in place, employee performance will be low, with a value of 0.099 on a scale of 1 to 5. This is supported by the following results: $\mathrm{RSq}=0.737$ and $\mathrm{F}=35.435$ with $\mathrm{Sig}$ $=0.000<0.05$ (significant). This indicates that the constant factor simultaneously with the independent variables have a significant effect on employee performance.

Organizational changes have no significant effect on employee performance which means that organizational change cannot be used alone to improve employee performance. This is demonstrated in the results of the calculated $\mathrm{t}$ value with a significance value of $>0.05$. However, given the calculated $\mathrm{RSq}=$ 0.737 and $\mathrm{F}=35.435$ with $\mathrm{Sig}=0.000<0.05$ (significant), organizational change can be used simultaneously with organizational culture and motivation to increase employee performance, with a $73.7 \%$ probability of success.

Organizational culture has no significant effect on employee performance, meaning that organizational culture cannot be used alone to improve employee performance. This is demonstrated in the results of the calculated $t$ value with a significance value of $>0.05$. However, considering the calculated $\mathrm{RSq}=0.737$ and $\mathrm{F}=35.435$ with $\mathrm{Sig}=0.000<0.05$ (significant), organizational culture can be used simultaneously with organizational change and motivation to increase employee performance, with a $73.7 \%$ probability of success.

Individual motivation does have a significant effect on employee performance, meaning that motivation can be used alone to improve employee performance. This is demonstrated by the calculated $t$ value with a significance value of $<0.05$. Given the calculated $\mathrm{RSq}=0.737$ and $\mathrm{F}=35.435$ with $\mathrm{Sig}=0.000<0.05$ (significant), motivation has an effect on employee performance and can be used simultaneously with organizational change and organizational culture to increase employee performance, with a $73.7 \%$ probability of success.

\section{Conclusions}

Based on the findings of the research, the following conclusions are made:

1. Management must pay attention to organizational change, organizational culture, and motivation to improve employee performance.

2. The main priority of employee performance policy should be the motivation of all employees. 
3. Organizational change and organizational culture both have an insignificant effect on employee performance, however, they can be used simultaneously to improve employee performance, together with motivation.

\section{Implications of the Study}

Motivation of employees has the ability to improve employee performance. The results of the study prove that the dimensions of intrinsic motivation have the most significant effect on employee performance compared to other external factors. Increasing employee motivation can be achieved by giving rewards for achievement, recognition of employee's work, providing job responsibilities, and developing employee potential.

In addition to increasing employee motivation, employers should aim to encourage a sense of community , teamwork and enthusiasm among employees. For this reason, the role of the leadership is crucial. Many organizations fail because they are over-managed but not led. Successful leaders build people and teams that are charismatic, caring, committed, full of clarity, communicative, consistent, creative, competent, and brave.

\section{References}

Bangun, Wilson. 2012. Human Resource Management. Erlangga. Bandung.

Benardin (2010). Human Resource Management, An Experimental Approach. Sixth Edition. McGraw-Hill. New York.

Brown Donald. R and Harvey Don. An Experimental Approach to Organization Development. Seventh Edition. Pearson Education. Inc., New Jersey.

Cooper, D. R. and Schindler, P. S. (2014). Business Research Methods. New York: McGraw-Hill.

Ghozali, Imam. (2006). Application of Multivariate Analysis with the SPSS Program (Second Edition). Diponegoro University Publishing Agency: Semarang.

Grifin W. Ricky, Phillips M. Jean, Gully M. Stanley. 2017. Organizational Behavior. Twelfth Edition. Cengage Learning 20 Channel Street Boston, MA 02210. USA.

Hasibuan, Malayu S. P (2007). Human Resource Management Revised Edition. PT. Earth Aksara. Jakarta.

Iffah Budiningsih, Tjiptogoro Dinarjo Soehari, Masduki Ahmad. (2017), Increased Competency Through Training Intervention. International Journal of Applied Business and Economic Research. Vol. 15(6).

Ivancevich. (2012). Human Resource Management. Twelve Edition. McGraw-Hill. New York.

Muhamad Darusalam and Tjiptogoro Dinarjo Soehari (2017). Organizational Culture, Organizational Climate, and Leadership Style Affected Teacher Performance. Journal Entrepreneur. Vol. XI(1). Pascasarjana Universitas Mercu Buana. Jakarta. ISSN:1858-3121.

Robbins, Stephen P. and Timothy A. Judge. (2007). Organizational Behavior. Twelfth Edition. Pearson Education. Inc., New Jersey.

Springer, Gary. (2011). A Study of Job Motivation, Job Satisfaction and Performances Among Bank Employees. European Journal of Business and Management. Vol. VII(34), pp. 259-277. ISSN 2222-1905 (Paper); ISSN 2222-2839 (Online).

Sugiyono. (2012). Quantitative, Qualitative and R \& D Research Methods. Alfabeta: Bandung.

Tjiptogoro and Djumarno (2018), The Strategic Role of Management of Human Resources to Prevent Corruption. Vol. 3(3). Journal of Business and Economics Review. GATR Enterprise.

Tjiptogoro, Iffah. (2017), Analysis of Strategic Factors of Human Resources Management for Corruption Prevention. Volume 15, Number 6, 2017. International Journal of Applied Business and Economic Research. Serial Publications Pvt. Ltd.

Tjiptogoro, Iffah, Bakdi. (2017), Performance Improvement through Human Capital Strategic for Civil Servant. Volume 15, Number 24, 2017. International Journal of Applied Business and Economic Research. Serial Publications Pvt. Ltd.

Tjiptogoro, Iffah, Fransica, Hapzi. (2017), Corruption Prevention and Deterrence Through Strategic Human Resources Management Vol: 6, Issue 1, January 2017. International Journal of Application or Innovation in Engineering \& Management. IJAIEM Index by Thomson Reuter \& Other. 
Tjiptogoro, Iffah, Havidz, Hastuti. (2017), Strategic Factors of Human Capital for Employees Performance Improvement Volume 14, Number 13, 2017. International Journal of Economic Research. Serial Publications Pvt. Ltd. Tjiptogoro, Iffah, Mirza. (2017), Managerial Leadership for Competitive Advantage University. Volume 15, Number 24, 2017. International Journal of Applied Business and Economic Research. Serial Publications Pvt. Ltd. 